\title{
Adherence of Helicobacter pylori to human gastric epithelial cells in vitro
}

\author{
S. G. HEMALATHA, B. DRUMM* and P. SHERMAN*†
} Division of Gastroenterology, Research Institute, The Hospital for Sick Children, and Departments of *Pediatrics and
†Microbiology, University of Toronto, Toronto, Ontario, M5G 1 X8, Canada

\begin{abstract}
Summary. Gram-negative spiral organisms, currently referred to as Helicobacter pylori, are associated with primary gastritis and duodenal ulceration. The organisms colonise gastric mucus and adhere to epithelial cells of inflamed antra. To further examine the binding of $H$. pylori to human gastric epithelial cells, we developed and characterised an in-vitro bacterial adherence assay. Scanning electronmicroscopy suggested that spiral-shaped bacteria were adherent to the surface of KATO-III cells which were derived from a human gastric adenocarcinoma. Transmission electronmicroscopy confirmed the attachment of $H$. pylori to these epithelial cells in tissue culture. Some bacteria were adherent to intact microvilli, others were closely adherent to the plasma membrane in regions where microvilli were effaced. In studies with radiolabelled $H$. pylori, adherence to epithelial cells in tissue culture contrasted with minimal binding of bacteria to polystyrene wells alone. Incubation of bacteria with gastric cells at $4^{\circ} \mathrm{C}$ significantly reduced adherence of $H$. pylori. We conclude that adherence of $H$. pylori to gastric epithelial cells in tissue culture involved "attachment and effacement mechanisms". This assay could serve as a suitable in-vitro model for the study of the bacterial adhesins and host receptors which mediate attachment of $H$. pylori to gastric epithelial cell surfaces.
\end{abstract}

\section{Introduction}

Gram-negative, spiral shaped organisms, now known as Helicobacter pylori (previously Campylobacter pylori $)^{1}$ have recently been associated with both antral gastritis and peptic ulcer in adults ${ }^{2,3}$ and children. ${ }^{4,5}$ Histological examination of diseased antral mucosa has demonstrated the presence of these bacteria within the gastric mucus layer and at the surface of gastric epithelial cells. ${ }^{6}$ Ultrastructural changes on the apical plasma membrane of gastric epithelial cells to which bacteria have adhered include loss of microvilli and the development of adherence pedestals. ${ }^{7,8}$ Bacterial attachment to adherence pedestals is also present in a ferret model of H.pyloriassociated disease. ${ }^{9}$ These changes appear morphologically identical to the attaching and effacing adherence phenomena which have been observed in the small intestine and colon in enteropathogenic Escherichia coli infection in animals. ${ }^{10}$

Binding of $H$. pylori to HEp-2 and INT-407 epithelial cells in tissue culture was described recently. ${ }^{11}$ However, characterisation of binding by $\boldsymbol{H}$. pylori to gastric epithelial cells in vitro has not been reported. Such an adherence assay could be used to identify the

Received 10 Sep. 1990; revised version accepted 4 Jan. 1991. $\uparrow$ Correspondence should be sent to Dr P. Sherman. adhesins expressed by $\boldsymbol{H}$.pylori and could serve as a model to determine the mechanism of bacterial adherence to gastric epithelial cells. Therefore, we examined the adherence of $\boldsymbol{H}$.pylori to KATO-III cells, an epithelial cell line derived from a human gastric adenocarcinoma. ${ }^{12}$ Binding of $\mathrm{H}$.pylori to KATO-III cells was examined by scanning and transmission electronmicroscopy (SEM and TEM) and by a quantitative adherence assay with radiolabelled bacteria.

\section{Materials and methods}

\section{Bacteria and growth conditions}

H. pylori strains LC-3 and LC-11 were isolated originally from the antral mucosae of two children with primary gastritis and associated duodenal ulcer. ${ }^{5,13}$ Strains were stored at $-70^{\circ} \mathrm{C}$, as described previously, ${ }^{14}$ until used in these studies. Brucella Broth (Gibco Laboratories, Madison, WI, USA) containing trimethoprim (Sigma Chemicals, St. Louis, MO, USA) $5 \mathrm{mg} / \mathrm{L}$ and vancomycin (Sigma) $10 \mathrm{mg} / \mathrm{L}$ was supplemented with fetal bovine serum (Boknek Laboratories, Ontario, Canada) $10 \%$ for the culture of $H$. pylori. ${ }^{14,15}$ After rapid thawing, $0.5 \mathrm{ml}$ of stored $H$. pylori culture was mixed with $11 \mathrm{ml}$ of supplemented Brucella broth in a $250-\mathrm{ml}$ Ehrlenmeyer flask. The flask was closed 
with a loosely fitted screw cap and placed inside an incubation jar which was then evacuated and flushed through with a gas mixture containing $\mathrm{CO}_{2} 10 \%, \mathrm{O}_{2}$ $5 \%, \mathrm{~N}_{2} 85 \%$. The sealed jar was then placed on a rotary shaker and incubated at $37^{\circ} \mathrm{C}$ with shaking at $100 \mathrm{rpm}$. After $24 \mathrm{~h}, 1 \mathrm{ml}$ of bacterial culture was transferred to fresh medium and re-cultured. The absence of bacterial contaminants was confirmed by subculture of broth on blood-agar plates incubated in air at $37^{\circ} \mathrm{C}$. The presence of $H$. pylori was confirmed by a positive urease reaction (Christensen's urea broth) and by inspection of bacterial morphology by phasecontrast microscopy. ${ }^{14,16}$

H. pylori produced smooth, translucent colonies on supplemented Brucella agar. To improve the accuracy of viable counts (cfu), tetrazolium salts $(4 \mathrm{mg} / \mathrm{L}$ ) were added into the agar medium, as described previously. ${ }^{17}$ After incubation for 5 days in micro-aerophilic conditions, H.pylori produced red colonies on this medium.

\section{Growth studies with $H$. pylori}

The growth curve for $H$. pylori in the broth cultures was constructed from sequential measurements of optical densities of cultures at $600 \mathrm{~nm}$ and from quantitation of viable bacteria by colony counts after incubation for $6,12,18,24,30$ and $36 \mathrm{~h}$. Viable counts were determined by inoculating dilutions of broth in triplicate on to Brucella agar with tetrazolium salts. Colonies were counted after incubation of plates for 5 days at $37^{\circ} \mathrm{C}$ in micro-aerophilic conditions.

\section{Radiolabelling of $\mathrm{H}$. pylori}

Tritium-labelled $(8 \cdot 3 \mu \mathrm{Ci} / \mathrm{ml})$ or ${ }^{14} \mathrm{C}$-labelled $(1 \cdot 7$ $\mu \mathrm{Ci} / \mathrm{ml}$ ) proline and histidine (New England Nuclear, Boston, MA, USA), were added to the growth medium at the time of inoculation with bacteria. H.pylori strain LC-3 was used for all radiolabelling studies. Incubation conditions were identical to those described above. When ${ }^{14} \mathrm{C}$-labelled proline and histidine were used, gases which were released into the culture jar were absorbed in Protosol (New England Nuclear). After incubation for $18 \mathrm{~h}$, bacteria were pelleted by centrifugation at $3000 \mathrm{~g}$ for $15 \mathrm{~min}$, washed three times in sterile phosphate-buffered saline (PBS), and resuspended in PBS to an optical density of 0.35 at $600 \mathrm{~nm}$. Incorporation of radioactive label into the bacteria was determined by counting disintegrations/ $\min (\mathrm{dpm})$ in a $\beta$-scintillation counter (Model LS 7500, Beckman Instruments, Palo Alto, CA, USA).

\section{Adherence assay}

KATO-III cells, obtained from the American Type Culture Collection, Rockville, MD, are gastric epithelial cells originally derived from a human gastric adenocarcinoma. ${ }^{12}$ The cells were grown in RPMI-
1640 medium (Flow Laboratories, McLean, VA, USA) supplemented with heat-inactivated fetal bovine serum (Bocknek Laboratories) $20 \% \mathrm{v} / \mathrm{v}$, penicillin $100 \mathrm{IU} / \mathrm{ml}$ and streptomycin $0.1 \mathrm{mg} / \mathrm{ml}$ (Flow Laboratories). Cells were cultured in polystyrene tissueculture flasks in an atmosphere of $\mathrm{CO}_{2} 5 \%$ in air and $98 \%$ humidity at $37^{\circ} \mathrm{C}$. Confluent growth was obtained when flasks were incubated for 8-10 days, changing the growth medium at least once every 3 days. Cells were counted by microscopy on a haemocytometer slide with phase-contrast microscopy; $c .10^{6}$ cells $/ \mathrm{ml}$ were initially attached to the polystyrene and $c .10^{4}$ cells $/ \mathrm{ml}$ remained in suspension.

In studies of bacterial adherence, KATO-III cells were subcultured and grown in 12-well tissue-culture cluster dishes. After 8-10 days, the number of gastric epithelial cells adherent to polystyrene was approximately $2 \times 10^{6}$ cells/well. For electronmicroscopy, the KATO-III cell monolayers were washed twice with Hanks's Balanced Salts Solution (HBSS; Flow Laboratories). $\boldsymbol{H}$. pylori cells grown in supplemented Brucella broth for $18 \mathrm{~h}$ were resuspended in RPMI-1640 without antibiotics (pH 7.6), and $0.5 \mathrm{ml}$ of medium containing $1 \times 10^{8} \mathrm{cfu}$ was then added to each well. Cluster dishes were incubated in micro-aerophilic conditions at $37^{\circ} \mathrm{C}$ for $3.5 \mathrm{~h}$. After incubation, wells were washed twice with HBSS to remove non-adherent bacteria. The KATO-III cells and adherent bacteria were then removed from the wells with a rubber scraper. Samples were prepared for SEM and TEM, as described previously. ${ }^{18}$

For quantitation of $\boldsymbol{H}$. pylori adherence to KATOIII cells, $10^{8}{ }^{3} \mathrm{H}$-labelled bacteria were resuspended in $1 \mathrm{ml}$ of RPMI-1640 (pH 7.6) without antibiotics and added to the wells of a cluster dish. Non-specific binding of bacteria to polystyrene was examined by incubation of an equal number of radiolabelled H. pylori in wells that did not contain KATO-III cells. The cluster dishes were incubated in micro-aerophilic conditions for $3.5 \mathrm{~h}$ at $37^{\circ} \mathrm{C}$. Non-adherent bacteria were then removed by six washes with $1 \mathrm{ml}$ of Dulbecco's PBS (Flow Laboratories). To remove adherent $\boldsymbol{H}$. pylori and KATO-III cells from the wells, trypsin (Flow Laboratories) $0.25 \% \mathrm{w} / \mathrm{v}$ was added and incubated at $37^{\circ} \mathrm{C}$ for $10 \mathrm{~min}$. The number of bacteria adherent to KATO-III cells and polystyrene surfaces was determined by counting dpm in $0 \cdot 1-\mathrm{ml}$ samples collected from each well after trypsinisation. Viability of KATO-III cells was determined at the beginning and end of the assays by trypan blue exclusion.

Adherence assays were also performed at $25^{\circ} \mathrm{C}$ and $4^{\circ} \mathrm{C}$ to determine whether binding of $\mathrm{H}$. pylori was temperature-dependent. The effect of decreasing the $\mathrm{pH}$ of the assay medium on bacterial attachment was examined by measurement of adherence of $H$. pylori to KATO-III cells at pH 5.0 and 2.0. To examine the effects of inhibition of bacterial protein synthesis on adherence, erythromycin lactobionate (Abbott Laboratories, Montreal, Quebec, Canada) was added to bacterial suspensions at sub-inhibitory concentrations 
$(0 \cdot 1$ and $1 \mathrm{mg} / \mathrm{L})$ and at an inhibitory concentration $(10 \mathrm{mg} / \mathrm{L}) 15 \mathrm{~min}$ before incubation with KATO-III cells. The minimum inhibitory concentration (MIC) of erythromycin for $H$. pylori strain LC-3 grown in broth culture was $5 \mathrm{mg} / \mathrm{L}$.

\section{Statistical analysis}

Results are expressed as mean and SEM. Differences between groups were calculated by the two-tailed unpaired Student's $t$ test. ${ }^{19}$

\section{Results}

\section{Growth of H. pylori}

As shown in fig. 1, turbidity and viable counts of $H$. pylori cultures reached a maximum within $18 \mathrm{~h}$. After $18 \mathrm{~h}$, clumping of bacteria and a decrease in motility were observed by phase-contrast microscopy. Numbers of viable bacteria also declined precipitously (fig. 1). Optical densities and viable counts of cultures were similar for a fresh isolate (strain LC-11) and an isolate (strain LC-3) that had been stored at $-70^{\circ} \mathrm{C}$ for 1.5 years after $18 \mathrm{~h}$ in supplemented Brucella broth. Viable bacterial counts indicated that cultures contained $2 \times 10^{8} \mathrm{cfu} / \mathrm{ml}$ at $18 \mathrm{~h}$. Growth of $H$. pylori in Brucella broth was reproducible when cultures were passaged serially after incubation for $15-18 \mathrm{~h}$. Bacteria had the spiral morphology typical of $H$. pylori seen in the human antrum in vivo.

\section{Incorporation of radiolabelled amino acids}

Incorporation of radioactive label into bacteria was determined after $18 \mathrm{~h}$ because the number of viable organisms and optical density in broth cultures was maximal at this time. Maximum incorporation of radiolabelled proline and histidine by $H$. pylori occurred after incubation for $18 \mathrm{~h}$ and label was retained by the organisms until the bacteria reached stationary phase. The growth curve for H.pylori in broth supplemented with proline was similar to that obtained without supplementation. The average incorporation of ${ }^{3} \mathrm{H}$-proline was $10^{-3} \mathrm{dpm} /$ bacterium. During the 3.5-h period used in the adherence assays, there was minimal elution of label from bacteria into the tissueculture medium ( $<5 \%$ of incorporated ${ }^{3} \mathrm{H}$ ). Under the conditions of these tests, tritiated amino acids were found to be more suitable for use in subsequent experiments because $H$. pylori released ${ }^{14} \mathrm{CO}_{2}$ when

${ }^{14} \mathrm{C}$ substrates were added to culture media.

\section{Adherence of H. pylori to KATO-III cells}

SEM suggested that attachment of spiral-shaped bacteria to the surface of KATO-III cells had occurred (fig. 2). TEM confirmed that $H$. pylori were adherent to KATO-III cells. Some bacteria were adherent to intact microvilli while others were closely bound to the plasma membrane of the gastric epithelial cells (fig. 3). Microvilli were absent at sites of close attachment and the plasma membrane of KATO-III cells was raised to form cup-like projections referred to as "pedestals" (fig. 3).

As shown in fig. 4, studies with radiolabelled $H$. pylori also confirmed their adherence to KATO-III cells (20 198 SEM $1434 \mathrm{dpm}$ ). In contrast, there was only minimal binding of organisms to polystyrene surfaces alone (738 SEM $103 \mathrm{dpm}, \mathrm{p}<0.00001$ ). Serial plating to quantitate the number of viable adherent organisms bound to KATO-III cells demonstrated that there were $\left(3.5 \times 10^{3}\right)-\left(4 \times 10^{5}\right) \mathrm{cfu} /$ well. These numbers were less than the $10^{7}$ bacteria/well expected from calculations based upon estimations of $\mathrm{dpm}$.

Binding of $\boldsymbol{H}$. pylori to KATO-III cells was greater at $37^{\circ} \mathrm{C}$ than at either room temperature or $4^{\circ} \mathrm{C}$ (fig. 4). The $\mathrm{pH}$ of assay medium ( $\mathrm{pH} 7.6$ ) remained stable at each of three ambient temperatures tested. At $\mathrm{pH} 5$, the number of $H$. pylori adhering to KATO-III cells was not reduced even though $>75 \%$ of gastric epithelial cells were no longer viable at the end of the incubation period. This figure contrasts with the finding that $>90 \%$ of the epithelial cells remained

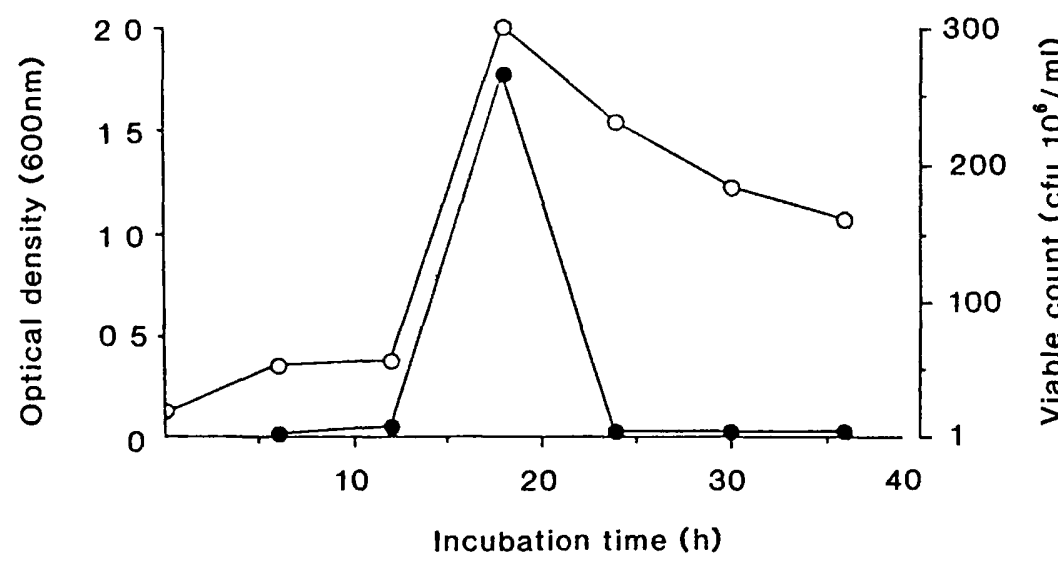

Fig. 1. Growth curve of $H$. pylori, strain LC-3. Optical density (O) (at $600 \mathrm{~nm})$ and colony-forming units (O) were determined every $6 \mathrm{~h}$ for $36 \mathrm{~h}$. 


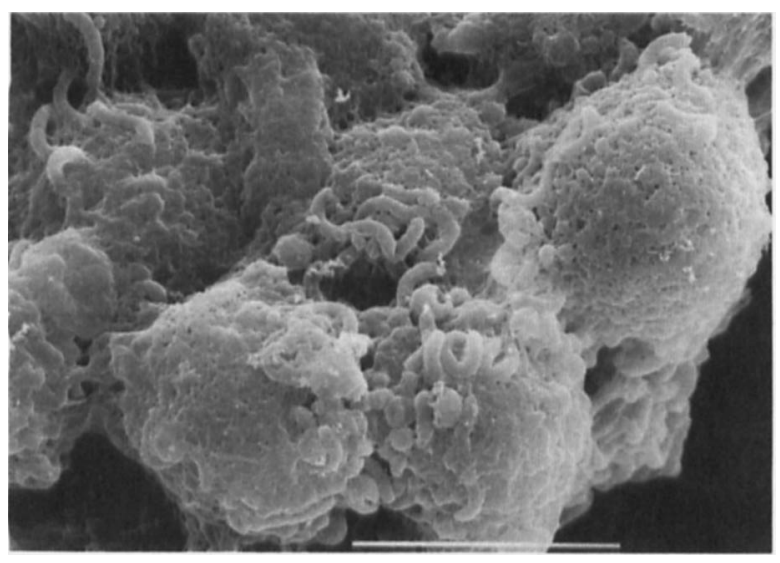

Fig. 2. Scanning electronmicrograph of $\boldsymbol{H}$. pylori strain LC-3 after incubation with KATO-III cells for $3.5 \mathrm{~h}$ at $37^{\circ} \mathrm{C}$.

viable at the end of the $3 \cdot 5-\mathrm{h}$ incubation period when the $\mathrm{pH}$ of the assay medium was 7.6 . In acidic conditions ( $\mathrm{pH} 2 \cdot 0$ ), bacterial adherence to KATOIII cells was significantly reduced (9298 SEM 255 dpm, $\mathrm{p}<0.001) ;<10 \%$ of gastric epithelial cells were viable after $3.5 \mathrm{~h}$ under these conditions.

Sub-inhibitory concentrations of erythromycin enhanced the binding of $\boldsymbol{H}$. pylori to KATO-III cellsat $0.1 \mathrm{mg} / \mathrm{L}, 39752 \mathrm{SEM} 4030 \mathrm{dpm}$ and at $1 \mathrm{mg} / \mathrm{L}$, 34419 SEM $6248 \mathrm{dpm}$. An inhibitory concentration of erythromycin $(10 \mathrm{mg} / \mathrm{L})$ did not affect adherence of the organisms (25 824 SEM $2470 \mathrm{dpm}$ ).

\section{Discussion}

Adherence of pathogenic bacteria to target cells is an important step in the pathogenesis of many bacterial diseases. ${ }^{20}$ For example, following attachment of organisms to gut mucosal surfaces, host tissues are exposed to higher concentrations of bacterial enterotoxins. ${ }^{21}$ Adherence is also important for entry of organisms into epithelial cells. ${ }^{22}$ However, little is

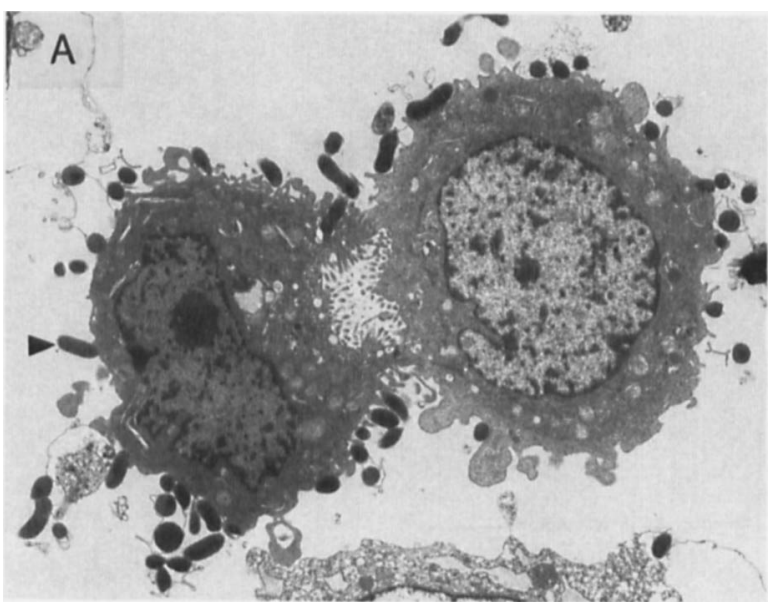

known about the factors that promote attachment to and colonisation of the gastric mucosa by the newlyrecognised pathogen $H$. pylori. Histological examination of biopsy specimens from the antrum of human stomach has revealed $H$. pylori within gastric mucus and adherent to the apical membranes of gastric epithelial cells. ${ }^{8}$ Depletion of microvilli and disruption of cytoskeletal filaments were observed at points of bacterial attachment. These adherence pedestals on the cell surface appeared morphologically identical to lesions observed in the small and large intestines in association with enteropathogenic $E$. coli infections. ${ }^{10,23}$

In the present study, we have demonstrated attachment of $H$. pylori to epithelial cells of gastric origin in vitro. Adherence of $\boldsymbol{H}$. pylori to KATO-III cells was morphologically identical to the in-vivo observations reported previously. ${ }^{6-8}$ Clinical isolates of $H$. pylori bind to, and mediate mannose-resistant haemagglutination of, erythrocytes derived from man and from several animal species. ${ }^{24-26}$ Evans et al. ${ }^{27}$ characterised a surface-associated haemagglutinin which is expressed by $\boldsymbol{H}$. pylori as a fibrillar adhesin. In-vitro studies showed that $H$. pylori also bind to HEp-2 and Intestine-407 human epithelial cell lines ${ }^{11}$ as well as Y-1 murine adrenal cells ${ }^{28}$ in tissue culture. Although these established cell lines are not derived from gastric epithelium, TEM has demonstrated that $H$.pylori adheres closely to the surface of plasma membranes.

In bacterial adherence assays, adherent bacteria can be counted by microscopy, live adherent bacteria can be quantitated by surface viable counts and attached labelled bacteria determined by measurements of radioactivity. As $H$. pylori requires incubation for $\geqslant 5$ days to achieve adequate growth on agar media, a rapid and reproducible method for quantitation of bacterial adherence with radiolabelled organisms was employed in most assays in this study. Due to the fastidious growth requirements of $H$. pylori in vitro, differences between numbers of adherent bacteria as estimated by measurement of dpm and viable counts can probably be accounted for by a decrease in numbers of viable organisms with time.

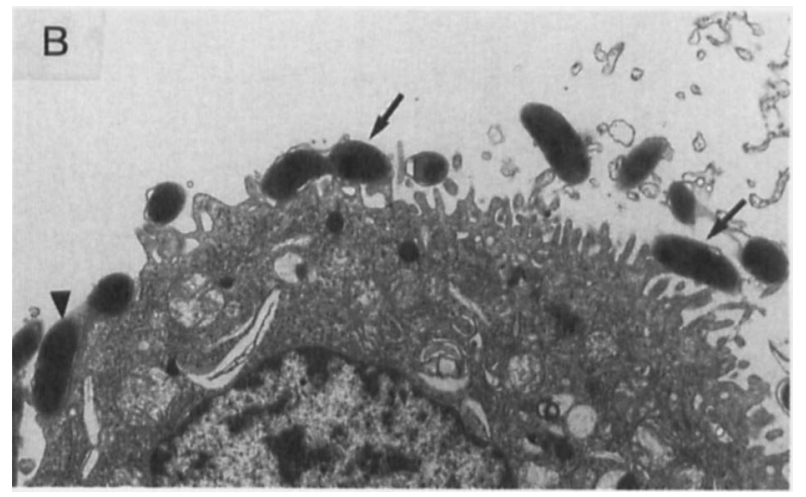

Fig. 3. Transmission electronmicrograph demonstrating adherence of $\boldsymbol{H}$. pylori to KATO-III cells after incubation for $3 \cdot 5 \mathrm{~h}$ (panel $\mathbf{A}$, $\times$ 7200). Some bacteria are adherent to microvilli on KATO-III cells (arrows), others (arrowheads) are attached to pedestals in regions where microvilli are disrupted (panel $\mathbf{B}, \times 10300$ ). 


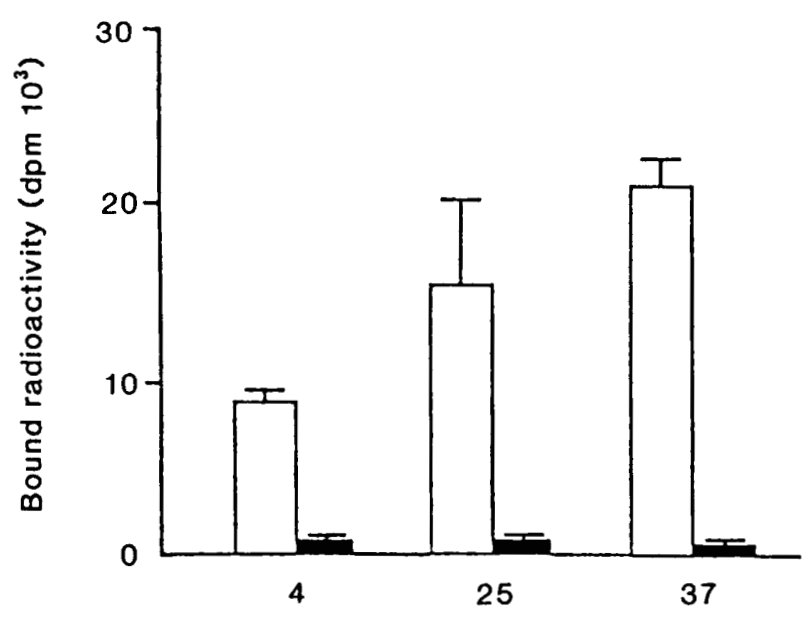

Temperature $\left({ }^{\circ} \mathrm{C}\right)$

Fig. 4. Adherence (dpm $10^{3} /$ well) of $H$. pylori strain LC-3 to KATOIII cells $(\square)$ and polystyrene surfaces $(\square)$ at $4^{\circ} \mathrm{C}, 25^{\circ} \mathrm{C}$ and $37^{\circ} \mathrm{C}$, bar, SEM.

Minimal binding of radiolabelled bacteria to plastic alone and the negligible loss of radioisotope from $H$. pylori both indicated that free radioisotope was not an important confounding variable in these experiments.

Adherence of $\boldsymbol{H}$.pylori to tissue-culture cells was significantly reduced at extreme acidity when compared to the binding of bacteria at $\mathrm{pH} 5.0$ or $\mathrm{pH} \mathrm{7.6}$. The reduction in bacterial binding to KATO-III cells at $\mathrm{pH} 2.0$ was probably related to reduced viability of organisms since Itoh et al. ${ }^{29}$ showed that $H$. pylori does not survive below pH 2.5. Nevertheless, since $<$ $10 \%$ of gastric epithelial cells were viable at this $\mathrm{pH}$ value, it is possible that receptors for binding of organisms were chemically modified in a strong acid environment. However, because the micro-environ-

\section{References}

1. Goodwin CS, Armstrong JA, Chilvers T et al. Transfer of Campylobacter pylori and Campylobacter mustelae to Helicobacter gen. nov. as Helicobacter pylori comb. nov. and Helicobacter mustelae comb. nov., respectively. Int J Syst Bacteriol 1989; 39: 397-405.

2. Marshall BJ, Warren JR. Unidentified curved bacilli in the stomach of patients with gastritis and peptic ulceration. Lancet 1984; 1 : 1311-1315.

3. Blaser MJ. Helicobacter pylori and the pathogenesis of gastroduodenal inflammation. $J$ Infect Dis $1990 ; 161$ : 626-633.

4. Drumm B, O'Brien A, Cutz E, Sherman P. Campylobacter pyloridis-associated primary gastritis in children. Pediatrics $1987 ; 80$ : 192-195.

5. Drumm B, Sherman P, Cutz E, Karmali M. Association of Campylobacter pylori on the gastric mucosa with antral gastritis in children. $N$ Engl J Med 1987 ; 316: 1557-1561.

6. Tricottet V, Bruneval P, Vire $\mathrm{O}$ et al. Campylobacter-like organisms and surface epithelium abnormalities in active, chronic gastritis in humans: an ultrastructural study. Ultrastruc Pathol 1986; 10: 113-122.

7. Bode G, Malfertheiner P, Ditschuneit H. Pathogenetic implications of ultrastructural findings in Campylobacter pylori related gastroduodenal disease. Scand J Gastroenterol 1988; 23 Suppl 142: 25-39. ment in which $H$. pylori resides in vivo is likely to be close to neutral $\mathrm{pH}$ further in-vitro characterisation of bacterial adherence was performed at $\mathrm{pH} 7 \cdot 6$. In addition, adherence of $\boldsymbol{H}$. pylori to KATO-III cells was a temperature-dependent process that was inhibited at $4^{\circ} \mathrm{C}$. Inhibition of $\mathrm{H}$. pylori binding at $4^{\circ} \mathrm{C}$ suggested that continuous bacterial protein synthesis was required for adherence.

Previous studies have shown that the expression and normal function of bacterial adhesins are variably inhibited or promoted by incubation of bacteria with subinhibitory concentrations of antibiotics. ${ }^{30}$ Therefore, the $H$. pylori adherence assay was performed in the presence of subinhibitory concentrations of erythromycin. Although ultrastructural changes, such as incomplete cell-wall development, have been observed when $H$. pylori is grown in inhibitory concentrations of erythromycin, ${ }^{31}$ our results indicated that subinhibitory concentrations of erythromycin enhanced the binding of $H$. pylori to epithelial cells in vitro. Increased bacterial attachment to eukaryotic cells in the presence of sublethal antibiotic concentrations has been demonstrated previously for other human pathogens including E.coli, Enterococcus faecalis and Streptococcus sanguis. ${ }^{30}$ The mechanism underlying enhanced binding of these organisms in the presence of certain antibiotics is not understood. ${ }^{30}$

The similarities observed between the binding of $H$. pylori to tissue culture cells and the adherence of the bacteria in vivo indicates that the adherence assay described will serve as a useful in-vitro model for investigations aimed at defining bacterial adhesin(s) and host receptor(s) which mediate attachment of $H$. pylori to eukaryotic cell surfaces.

P.S. is the recipient of a Career Scientist Award from the Ontario Ministry of Health.

8. Goodwin CS, Armstrong JA, Marshall BJ. Campylobacter pylori, gastritis, and peptic ulceration. J Clin Pathol 1986; 39: 353-365.

9. Fox JG, Correa P, Taylor NS et al. Helicobacter mustelaeassociated gastritis in ferrets. An animal model of Helicobacter pylori gastritis in humans. Gastroenterology 1990; 99: 352-361.

10. Moon HW, Whipp SC, Argenzio RA, Levine MM, Giannella RA. Attaching and effacing activities of rabbit and human enteropathogenic Escherichia coli in pig and rabbit intestines. Infect Immun 1983; 41: 1340-1351.

11. Neman-Simha V, Mégraud F. In-vitro model for Campylobacter pylori adherence properties. Infect Immun 1988; 56: 33293333.

12. Sekiguchi M, Sakakibara K, Fujii G. Establishment of cultured cell lines derived from a human gastric carcinoma. Japan J Exp Med 1978; 48: 61-68.

13. Lingwood CA, Law H, Pellizzari A, Sherman P, Drumm B. Gastric glycerolipid as a receptor for Campylobacter pylori. Lancet 1989 ; 2 : 238-241.

14. Drumm B, Sherman P. Long-term storage of Campylobacter pylori. J Clin Microbiol 1989; 27 : 1655-1656.

15. Morgan DR, Freedman R, Depew CE, Kraft WG. Growth of Campylobacter pylori in liquid media. J Clin Microbiol 1987; 25: 2123-2125.

16. Westblom TU, Madan E, Kemp J, Subik MA. Evaluation of a rapid urease test to detect Campylobacter pylori infection. $J$ Clin Microbiol 1988; 26 : 1393-1394. 
17. Queiroz DMM, Mendes EN, Rocha GA. Indicator medium for the isolation of Campylobacter pylori. J Clin Microbiol 1987; 25: 2378-2379.

18. Sherman P, Fleming N, Forstner J, Roomi N, Forstner G. Bacteria and the mucus blanket in experimental small bowel bacteria overgrowth. Am J Pathol 1987; 126: 527 534.

19. Colton T. Statistics in medicine. Boston, Little, Brown and Co. 1974.

20. Beachey EH. Bacterial adherence: adhesin-receptor interactions mediating the attachment of bacteria to mucosal surfaces. $J$ Infect Dis 1981 ; 143: 325-345.

21. Zafriri D, Oron Y, Eisenstein BI, Ofek I. Growth advantage and enhanced toxicity of Escherichia coli adherent to tissue culture cells due to restricted diffusion of products secreted by the cells. $J$ Clin Invest $1987 ; 79: 1210-1216$.

22. Finlay BB, Heffron F, Falkow S. Epithelial cell surfaces induce Salmonella proteins required for bacterial adherence and invasion. Science 1989 ; 243 : 940-943.

23. Knutton S, Baldwin T, Williams PH, McNeish AS. Actin accumulation at sites of bacterial adhesion to tissue culture cells: basis of a new diagnostic test for enteropathogenic and enterohemorrhagic Escherichia coli. Infect Immun 1989; 57: 1290-1298.

24. Emödy L, Carlsson $\AA$, Ljungh $\AA$, Wadström T. Mannose- resistant haemagglutination by Campylobacter pylori. Scand $J$ Infect Dis 1988; 20 : 353-354.

25. Huang J, Smyth CJ, Kennedy NP, Arbuthnott JP, Keeling PWN. Haemagglutinating activity of Campylobacter pylori. FEMS Microbiol Lett 1988; 56: 109-112.

26. Nakazawa $T$, Ishibashi $M$, Konishi $H$, Takemoto $T$, Shigeeda M, Kochiyama T. Hemagglutination activity of Campylobacter pylori. Infect Immun 1989; 57 : 989-991.

27. Evans DG, Evans DJ, Moulds JJ, Graham DY. N-acetylneuraminyllactose-binding fibrillar hemagglutinin of Campylobacter pylori: a putative colonization factor antigen. Infect Immun 1988; 56: 2896-2906.

28. Evans DG, Evans DJ, Graham DY. Receptor-mediated adherence of Campylobacter pylori to mouse Y-1 adrenal cell monolayers. Infect Immun 1989; 57: 2272-2278.

29. Itoh T, Yanagawa Y, Shingaki M et al. Isolation of Campylobacter pyloridis from human gastric mucosa and characterisation of the isolates. Microbiol Immunol 1987; 31 : 603614.

30. Schifferli DM, Beachey EH. Bacterial adhesion: modulation by antibiotics with primary targets other than protein synthesis. Antimicrob Agents Chemother 1988; 32: 1609-1613.

31. Armstrong JA, Wee SH, Goodwin CS, Wilson DH. Response of Campylobacter pyloridis to antibiotics, bismuth and an acid-reducing agent in vitro: an ultrastructural study. $J \mathrm{Med}$ Microbiol 1987; 24 : 343-350. 